\title{
The Effect of Tutorial Video Use and Prerequisite Skills on Students' MYOB Accounting Performance
}

\section{Syofriani ${ }^{1}$, Efrizal Syofyan ${ }^{2}$, Marwan $^{3}$}

${ }^{1}$ Faculty of Economics, Universitas Negeri Padang, Indonesia

$\square$ (e-mail) nie_yanie@ymail.com

2Dept. of Accounting, Faculty of Economics, Universitas Negeri Padang, Indonesia

$\triangle$ (e-mail) efrizal_sofyan@yahoo.com

${ }^{3}$ Dept. of Economics Education, Faculty of Economics, Universitas Negeri Padang, Indonesia

$\square$ (e-mail) marwan@fe.unp.ac.id

\begin{abstract}
This study aims to investigate: (1) the difference in MYOB accounting learning performance of students taught by using tutorial video as a learning media and those taught by using power point in a conventional type of learning, (2) the difference in MYOB accounting learning performance of students with high level of prerequisite competence and those with low level of prerequisite competence, (3) the interaction between the use of tutorial video as a learning media and prerequisite competence in MYOB accounting learning. This study is a quasi-experimentation research with a population of all students of class XII.K in state vocational high school (Sekolah Menengah Kejuruan Negeri-SMKN) 1 Batusangkar. The sampling technique used was purposive sampling. The sample in this study was students of class XII.K1 as the experimental class and students of class XII.K2 as the control class. The data analysis technique employed was two-way ANOVA. The findings of this study demonstrated that (1) MYOB accounting learning performance of the students taught by using tutorial video tutorial was higher than those taught by using power point in a conventional learning setting, (2) students with high level of prerequisite competence showed better learning performance compared to those with poor mastery of the competence required for MYOB accounting learning, (3) there is no interaction between instructional media and prerequisite competence on $\mathrm{MYOB}$ accounting learning of $12^{\text {th }}$ grade students in SMKN 1 Batusangkar.
\end{abstract}

Keywords: tutorial video, prerequisite competence, and learning performance

\section{Introduction}

Student's learning performance in MYOB Accounting class in the state vocational high school (Sekolah Menengah Kejuruan Negeri-SMKN) 1 Batusangkar still needs a lot of improvement and therefore required serious attention from the teachers in charge. A preliminary study shows that the average score of MYOB accounting of XII.K1 and XII.K2 classes on daily tests were of 74.56 and 73.87. This means that the average score still falls far below the minimum standard criteria. The minimum standard criteria determined by the school is 80 , without exception for MYOB accounting subject in SMKN 1 Batusangkar which is considered as one of essential subjects for students with focus on accounting field.

Students' poor performance in computer accounting class can be attributed to many possible factors. The first reason is because of low mastery of prerequisite competence such as English skills. English skill becomes important when it comes to MYOB Accounting class since the software is set in English. Students with low mastery of English therefore will find it difficult to operate the software which in turn results in low learning performance for the subject. In other words, English skill is one of the predictors of students' success in MYOB accounting class. 
In relation to the problem, each teacher must take into consideration all student-related factors when selecting learning media that will be used during the learning process on a daily basis. Selecting appropriate instructional media is oriented towards the purpose of teaching, and therefore must consider the objectives of each learning topic that will be discussed on that session. One of the learning media that can be used is tutorial video. The use of tutorial video during MYOB accounting learning can help teacher optimize the delivery of the lesson and at the same time saves their energy because the teachers would not have to explain the learning materials in a conventional way. Besides that, students are also encouraged to learn independently. If the students do not understand the material then they can simply replay the video that has been made available. In addition, by using video tutorial media students would not easily get saturated during the learning because their attention will be poured fully on the video.

Learning media in the form of instructional video can be a great solution to overcome the existing problems in the school, so that learning becomes more effective and students can also learn to grasp the lesson independently. Riyana $(2007,147)$ stated that tutorial model is learning through computer where students are conditioned to follow the learning path that has been programmed by the presentation of material and exercise questions, in this case it can be concluded that tutorial video is a series of learning through computer where students are conditioned to follow the learning path that has been programmed by the presentation of audio-visual subject matter and exercises to assist students in understanding the learning material. It suffices to say that tutorial video in this case serves as a guidance during the learning process.

Tutorial media is a computer-based interactive learning media which is designed to be used by students individually (self-study). When students apply this program, they are invited to engage audibly, visually, and kinetic, so that with this engagement it is possible that the information or message is easy to understand (Munadi, 2010,152). Tutorial media can also improve student learning outcomes. According to Munadi $(2010,152)$, the use of tutorial media is effective enough to improve students' learning outcomes. The use of learning media through computer during the learning will make the learning activities more effective and efficient so that students' learning outcomes can also be improved (Wena, 2009, 204).

Based on the above explanations, this study aims to empirically examine the effect of tutorial video use and prerequisite skills on MYOB accounting results. This study focuses the examination on the study results of 12th grade students at SMK Negeri 1 Batusangkar. The hypotheses formulated for this study are as follows.

$\mathrm{H}_{1}$ The MYOB learning performance of students taught by using tutorial video is significantly higher than those taught by using conventional learning method

$\mathrm{H}_{2}$ The MYOB learning performance of students who possess high level of prerequisite skills is significantly higher than that of students with low mastery of prerequisites skills

$\mathrm{H}_{3}$ There is an interaction between instructional media and prerequisite competence on MYOB accounting performance

\section{Methods}

This research is an experimental quasi study with factorial design of $2 \times 2$ conducted in SMKN 1 Batusangkar. The population of this study was all $12^{\text {th }}$ grade students of accounting classes in SMKN 1 Batusangkar which consists of two classes, with the total of 67 students. The researchers used simple random sampling technique. Researchers randomly selected two of the accounting classes in SMKN 1 Batusangkar. Based on this randomization, the selected classes were XII.K.1 and XII.K2 classes. The first serves as experimental class, while the later was set as control class. The author only incorporated two classes as to avoid interrupting the whole learning process at school level.

The instruments used included questionnaire and test to measure student's level of prerequisite competence and MYOB Accounting learning performance. Details of each variable and how to 
measure it can be written as follows. First, prerequisite skills in MYOB learning context can be defined as a set of abilities that students must possess in order to be able to follow the lesson well. Prerequisites for MYOB accounting can be some prior knowledge of computers, windows operating system, English skills, and adequate mastery of financial accounting. In this study, prerequisites that is incorporated included English skills and student's mastery of financial accounting. The level of students' prerequisite knowledge is measured by checking their exam score in the first semester; for financial accounting and English subjects.

Scond, MYOB Accounting Test. Physical achievement test is a test used to measure the ability of learners within a certain time after the tutorial video media is played and conventional learning methods are applied. It is in the form of objective test (multiple choices) as much as forty (40) items written in accordance to the lesson topic. This test is given at the end of the meeting after applying tutorial video learning media and conventional learning method with the help of power point presentation. Prior to the use, the instrument must first be evaluated by the assessor and then tested to see the validity and reliability of the instrument. This is done to guarantee that the students' learning performance measure is not bias. The data obtained from MYOB Accounting learning outcomes were analyzed quantitatively to illustrate the characteristics of the learner's score after both of these learning media were implemented. After the data is collected, the next step is to analyze and process the data.

The instrument used in this research is MYOB accounting learning test. Before this instrument is used, it must first be tested outside the sample but still within the population to determine the validity of the content and the empirical validity of the instrument. The pilot test was conducted in SMKN 3 Padang that were not included in this study sample. It was done in class XI1.K1.

Validity is a measure that indicates the level of validity of an instrument (Arikunto, 2010, 11). An instrument can only be used further in the study only if it fulfills the criteria of validity. Conversely, if the instrument does not meet the criteria then it cannot be used as a tool to measure the variables.

Test of validity of the instrument was processed by using SPSS 16 for windows. The measured validity is seen in corrected item-total correlation in the SPSS view of the reliability test. Corrected item-total correlation is the correlation between the corresponding item and all other remaining items. If the Corrected Item-Total Correlation value is negative or smaller than $r$ table (for $n=34$, rable $=$ $0.339)$ then the item number is invalid and vice versa if the value is positive or higher than rable value (for $\mathrm{n}=34$, rtable $=0.339$ ) then the item number is valid (Idris, 2011).

Based on the validity test results obtained, among 40 questions there are 6 invalid questions. The invalid question items were question number 4, 7, 12, 16, 24, and 32. These invalid questions are not included in the test.

The next important step is to check the instrument's reliability. According to Arikunto $(2010,178)$, an instrument is considered reliable if it generates consistent and stable results. Reliability is a requirement for the validity of a test. Unreliable tests are by itself invalid. This study uses single testsingle trial approach by using Spearman-Brown split half formula for reliability test (Sudijono, 2009, 213). Based on the reliability test results, it is concluded that the instrument is reliable as the $r$ coefficient is of 0,947 . This can also be interpreted that the instrument was highly reliable.

The data collected in this research were MYOB accounting learning outcomes obtained by using MYOB accounting test. Whereas, the data on prerequisite skills was obtained from the students' exam scores for financial accounting and English subjects in the first semester.

The data were analyzed using inferential statistical analysis. Inferential statistical analysis employed to test the hypothesis in this study was two-way ANOVA. 


\section{Results and Discussion}

The data analysis was conducted by comparing the MYOB accounting test results between experimental class and control class group. The results of hypotheses test using two-way ANOVA are presented in Table 1. The results are significant if the $\mathrm{F}$ value is greater than or equal to Ftable with a significance level of 0.05 .

Table 1 Two-way ANOVA Results

\begin{tabular}{|c|c|c|c|c|c|}
\hline Source & $\begin{array}{c}\text { Type III Sum of } \\
\text { Squares }\end{array}$ & $\mathrm{df}$ & Mean Square & $\mathrm{F}$ & Sig. \\
\hline Corrected Model & $4227.398^{a}$ & 3 & 1409.133 & 18.720 & 0.000 \\
\hline Intercept & 423672.774 & 1 & 423672.774 & 5628.465 & 0.000 \\
\hline Media & 892.650 & 1 & 892.650 & 11.859 & 0.001 \\
\hline Prerequisites & 2985.997 & 1 & 2985.997 & 39.669 & 0.000 \\
\hline Media *Prerequisites & 288.206 & 1 & 288.206 & 3.829 & 0.055 \\
\hline Error & 4742.214 & 63 & 75.273 & & \\
\hline Total & 440815.000 & 67 & & & \\
\hline Corrected Total & 8969.612 & 66 & & & \\
\hline
\end{tabular}

The first hypothesis proposed that the MYOB accounting results of students taught by using tutorial video is significantly higher than those taught by using conventional learning method. The results in Table 2 show that $\mathrm{F}$ value of 11.859 which is higher than $\mathrm{F}$ table of 3.98 with a significance level of 0.001 which is lower than alpha 0.05 . Thus, $\mathrm{H}_{1}$ is supported. In other words, there is enough evidence to suggest that there is a significant difference in learning performance of students taught by using tutorial video as the learning media compared to students taught in conventional learning with the help of power point presentation in XII.K in SMKN 1 Batusangkar.

The findings are similar to previous research conducted by Sardiman $(2007,95)$ which show that learning process in which students are fully engaged and encouraged to be actively involved in the learning activities is the most ideal one. In other words, an ideal learning is a learning wherein students are actively involved in the learning. Learning process will not run well when students' activities are missing. By using tutorial video, students are fully engaged in the learning activities, both intellectually and emotionally, so that students really participate and involve themselves thoroughly in following the learning activities so that the learning objectives can be better achieved. Heru (2016) also shows that MYOB accounting performance of students taught by using tutorial learning strategies are better than those who received drill learning strategies.

The second hypothesis proposed that the MYOB accounting results of students who possess high level of prerequisite skills is significantly higher than that of students with low mastery of prerequisites skills in the context of MYOB Accounting learning. This is conducted by dividing the students' MYOB accounting scores based on the level of their prerequisite skills. The students were divided into two groups, a group with high and low prerequisite skills based on the mean value of prerequisite skills. Students with prerequisite skills value above the means were assigned to the high group and those with prerequisite skills value below the average were placed in the low group. Then the results of computer accounting learning of students with high prerequisite skills were compared to those with low prerequisite skills.

The results in Table 2 show the $\mathrm{F}$ value of 39.669 which is higher than $\mathrm{F}$ table of 3.98 with a significance level of 0.000 which is lower than alpha 0.05 . Thus, $\mathrm{H}_{2}$ is supported. In other words, there is sufficient evidence to suggest that the learning performance of students with high prerequisite skills is significantly higher compared to those students with low prerequisite skills. This also implied that students who do well on financial accounting and English subjects are more likely to get higher scores on MYOB Accounting subject. 
The results implied that good mastery of English and financial accounting as the prerequisites for MYOB learning can be a great assistance for the students to grasp the lesson better, which in other words means these two subjects has a positive impact on their learning performance. Being good at these two subjects helps students better understand the problem or work orders of computer accounting compared to students who have low mastery of these prerequisite skills. This is in accordance with study findings of Muhammad $(2000,74)$ which stated that students' basic ability or prerequisite skills is a state of knowledge or skills that must be possessed by students before they learn new knowledge or skills.

In addition to English language skills, other factors that are considered to be the determinant of MYOB learning performance is basic accounting knowledge (Albertus, 2001). Rifa'i and Catarina (2009) state that a series of factors that contribute to learning is the ability that has been owned before the new learning activities. The capabilities referred to in this study are financial accounting and English skills, which we refer to as prerequisite skills.

The third hypothesis proposed that there is an interaction between instructional media and prerequisite competence on MYOB accounting results. The results in Table 2 show F value of 3,829 which is lower than $\mathrm{F}$ table of 3.98 with a significance level of 0.055 which is higher than alpha 0.05 . Thus, $\mathrm{H}_{3}$ is rejected, in other words, there is adequate evidence that suggested that there is no interaction between the use of tutorial video as a learning media and financial accounting and English competence as prerequisite skills in MYOB Accounting learning of 12th grade students in SMK Negeri 1 Batusangkar. In other way, there is no significant interaction between learning media and financial accounting and English skills in influencing students' learning outcomes for MYOB accounting.

Irianto $(2010,255)$ explains that, if the hypothesis is not supported, it means that the effect of factor A does not depend on factor B, and the effect of factor B is also independent of factor A. Learning media and the prerequisite skills of financial accounting and English are independent of one another in influencing the student's MYOB learning outcomes. Kerlinger (2002) further explains that the interaction means the influence of an independent variable to a dependent variable, depending on the level of other independent variables. In this study, learning media and prerequisite skills (financial accounting and English) are two independent variables that do not affect the results of MYOB Accounting as dependent variable. Thus, the influence of tutorial media use on MYOB accounting performance is not dependent on the financial accounting and English skills of the students.

\section{Conclusions}

This study aims to investigate: (1) the difference in MYOB accounting learning performance of students taught by using tutorial video as a learning media and those taught by using power point in a conventional type of learning, (2) the difference in MYOB accounting learning performance of students with high level of prerequisite competence and those with low level of prerequisite competence, (3) the interaction between the use of tutorial video as a learning media and prerequisite competence in MYOB accounting learning. This study is a quasi-experimentation research with a population of all students of class XII.K in state vocational high school (SMKN) 1 Batusangkar. The sampling technique used was purposive sampling. The sample in this study was students of class XII.K1 as the experimental class and students of class XII.K2 as the control class. The data analysis technique employed was two-way ANOVA.

Several important findings of this study are as follows. First, the results of MYOB accounting learning of students taught by using tutorial video as the learning media is higher than those taught by using conventional learning method. This also implied that tutorial video can be a great choice to improve MYOB learning results. Second, students with high financial accounting and English skills have better MYOB learning outcomes compared to students with low financial accounting and English skills. This shows that the high level of mastery in financial accounting and English can be 
beneficial to students when it comes to MYOB learning. Third, there is no interaction between learning media and financial accounting and English abilities on MYOB learning outcomes. The results suggest that learning media used is accepted for all 12th grade students in SMK Negeri 1 Batusangkar, both with high and low financial accounting and English skills.

\section{References}

Albertus, O. (2001). Menggunakan MYOB Premier Accounting 18. Jakarta PT Elec Media Komputindo. Arikunto, Suharsimi. (2010). Prosedur Penelitian Suatu Pendekatan Praktek. Jakarta: Regina Cipta Sadiman.

Arief. (2007). Media Pendidikan, Pengertian, Pengembangan dan Pemanfaatannya. Jakarta: Rajawali.

Idris. (2012). Pelatihan Analisis SPSS. Himpro Manajemen Fakultas Ekonomi UNP: Padang.

Irianto, Agus. (2010). Statistik, Konsep Dasar dan Aplikasinya. Jakarta: Kencana Prenada Media Group.

Kerlinger, F. N. (2002). Asas-Asas Penelitian Behavioral. Diterjemahkan oleh Landung R. Simatupang. Yogyakarta: Gadjah Mada University Press.

Made, Wena. (2009). Strategi Pembelajaran Inovatif Kontemporer: Suatu Tinjauan Konseptual Operasional. Jakarta: Bumi Aksara.

Muhammad, Arni. (2000). Komunikasi Organisasi. Jakarta: Bumi Aksara.

Munadi, Yudhi. (2010). Media Pembelajaran: Sebuah Pendekatan Baru. Jakarta: Gaung Persada Press.

Rifai, Achmad \& Tri, Anni Chatarina. (2009). Psikologi Pendidikan. Semarang: UPT UNNES.

Riyana, Cheppy. (2007). Pedoman Pengembangan Media Video. Jakarta: P3AI UPI.

Sriyono, Heru. (2016). Effect of tutorial instructional strategy and drill in using MYOB accounting in vocational high school Bekasi West Java Province. Journal of Education and Vocational Research. 7(4), 37-40. ISSN 2221-2590.

Sudijono, Anas. (2009). Pengantar Evaluasi Pendidikan. Jakarta: Rajawali Press. 